\title{
Voluntary Work during Times of Military Crisis: What Motivates People to Be Involved and What Are the Effects on Well-Being?
}

\author{
Kateryna Karhina', Mehdi Ghazinour ${ }^{2}$, Nawi Ng$^{1,3}$, Malin Eriksson ${ }^{4}$ \\ ${ }^{1}$ Department of Public Health and Clinical Medicine, Epidemiology and Global Health, Umeå University, Umeå, Sweden \\ ${ }^{2}$ Police Education Unit at Umeå University, Umeå, Sweden \\ ${ }^{3}$ Center for Demographic and Aging Research, Umeå University, Umeå, Sweden \\ ${ }^{4}$ Department of Social Work, Umeå University, Umeå, Sweden \\ Email: ka teryna.karhina @gmail.com
}

How to cite this paper: Karhina, K., Ghazinour, M., Ng, N., \& Eriksson, M. (2017). Voluntary Work during Times of Military Crisis: What Motivates People to Be Involved and What Are the Effects on Well-Being? Psychology, 8, 1601-1619. https://doi.org/10.4236/psych.2017.810106

Received: July 6, 2017

Accepted: August 26, 2017

Published: August 29, 2017

Copyright $\odot 2017$ by authors and Scientific Research Publishing Inc. This work is licensed under the Creative Commons Attribution International License (CC BY 4.0).

http://creativecommons.org/licenses/by/4.0/ (c) (i) Open Access

\begin{abstract}
The positive health effects of volunteering are quite well described in the literature; however, potential negative effects of volunteering are less explored. Volunteering got attention in Ukraine because of the recent political crisis that brought military conflict to the Eastern part of the country in 2014. Informal volunteering has transformed into a formal one. In order to be able to organize volunteering that promotes well-being, it is important to have more in-depth knowledge about motives behind volunteering as well as the positive and potential negative effects of it. We explore the case voluntary work in of one of the cities in Ukraine. Military conflict context has its own specifics and different motives make people act voluntarily. There are goal-oriented, value-oriented, affectual and traditional motives present in our data. The data shows that involvement in volunteering brings positive returns on well-being of the providers such as enlarging the circles of friendship and expanding the networks volunteers involved in; brings positive emotions into life; compensates the efforts and gives meaning to life. However, the negative effects of volunteering are also present. They are physical tiredness and a lot of time spent on volunteering activities; becoming disconnected from the ordinary (non-volunteering) world; unsafety; neglect of own needs and experiences of negative emotions out of the involvement in volunteering activities.
\end{abstract}

\section{Keywords}

Volunteering, Motives, Health and Well-Being, Social Capital, Military Conflict, Ukraine 


\section{Introduction}

Volunteering is a phenomenon that has attracted scientists relatively recently. It receives interest from economists, politicians, sociologists, and psychologists for the reason that it carries the potential benefits such as filling the unemployment gap, ability to carry out welfare functions, capacity to expand social capital and others (Grizzle \& Yusuf, 2015; Ziemek, 2006). Health researchers and workers are interested in the possible positive health effects of volunteering as well. But what is meant by volunteering? In 2001, the United Nation released a Practical Tool for Measuring Volunteering in quantitative surveys (Dingle, Sokolowski, Saxon-Harrold, Smith, \& Leigh, 2001). The tool defines three main criteria characterizing volunteering: 1 ) it should be done without any financial interest; 2) it should be a free willing activity; and 3) it should bring benefits both to the third party as well as for the volunteers themselves. In addition, there are two major forms of volunteering: formal-within established entities or organizations, and informal-any volunteering activity carried out, although not through formal organizations (Lee \& Brudney, 2012).

Research supports that volunteering has positive effects on both the provider and the recipient by increasing their quality of life (Wilson, 2000; Weinstein \& Ryan, 2010). Volunteering by the provider may enlarge political involvement, provide possibilities to develop civic skills, and decrease antisocial behaviour (Wilson, 2000). It has also been shown to have positive physical and mental health effects. The former goes through better social ties and the latter goes through the integration into the community, a sense of belonging that prevents depression, enhances happiness etc. (Wilson, 2000; Wilson \& Musick, 1999; Rietschlin, 1998). However, when it comes to informal volunteering, i.e. non-formalized voluntary activities, we know less about the consequences and effects.

Volunteering got attention in Ukraine because of the recent political crisis that brought military conflict to the Eastern part of the country in 2014. Even though military actions take place only in one part of the country, men from all over Ukraine are drafted to fulfill military duty to protect their country. Due to material scarcity and fear of the enemy's invasion into the country, volunteering emerged to answer the needs of the protectors/soldiers by setting up voluntary service centres. In most cases, these were spontaneously organized and informal activities in the very beginning, but later turned to become "formal" voluntary unities/services. Thus, a lot of volunteering activities emerged as a response to a revolution (which took place in 2013-2014) and transformed into more formal and organized volunteering activities towards the military conflict (that started in 2014). Different types of social support were provided through these activities such as informational, instrumental, as well as emotional and companionship support (Karhina, Ghazinour, Ng, \& Eriksson, 2017). Military actions have influenced the well-being of those who are involved in military actions, people who live at the territory where it happens, volunteers who are actively involved in helping and the rest of the population in a secondary way. 
Volunteering can be linked to (or seen as a part of) the concept of social capital. Further, research has shown that social capital is associated with health and well-being (see e.g. Yip et al., 2007; Wilson, 2012; Yeung, 2004; Leung et al., 2013). Social capital has been viewed as a determinant of volunteering (Grizzle \& Yusuf, 2015) and an antecedent of it (Wollebaek \& Selle, 2007). Grizzle and Yusuf (2015) present a conceptual model of the pathways between volunteering and social capital. According to them, the connection between social capital and volunteering goes through: generalized trust, subjective well-being and religious activity. Formal volunteering generates social capital through existing relations within their activities and, at the same time provides resources needed for volunteering such as trust, information, and connectedness (Wilson \& Musick, 1998). The positive health effects of both social capital and volunteering are quite well described in the literature; volunteers e.g. show less signs of depression (Weinstein \& Ryan, 2010), and report better health and more happiness (Borgonovi, 2008). However, the potential negative effects of volunteering, as well as social capital, are less explored (Schwartz \& Sendor, 1999). In order to be able to organize volunteering that promotes well-being, it is important to have more in-depth knowledge about motives behind volunteering as well as the positive and potential negative effects of it. In addition, there is a lack of knowledge on how social capital can be mobilized and created for health promoting purposes (Eriksson, 2011). Understanding the mechanisms and motives behind volunteering might also help in filling this knowledge gap.

This paper builds on a case study of a military conflict situation in Ukraine when informal volunteering, which later turned into more formal activities, emerged as a response to this societal crisis. The aims of the study were to explore motives for people to become involved in volunteering in times of military conflict and to investigate the effects of volunteering on the well-being of volunteers in Ukraine.

Despite a growing amount of research on well-being, there is no agreement on how it should be defined, since the concept is complex and multidimensional. For the purpose of this paper, we will follow the definition proposed by Dodge et al. in 2012: "The balance point between individual's resource pool and the challenges faced... stable well-being is possible when individuals have the psychological, social and physical resources they need to meet a particular psychological, social andlor physical challenge" (p. 230). This definition is broad and simple enough to allow universal application while also embracing the interplay between resources (in our study they are returns) and challenges (Dodge, Daly, Huyton, \& Sanders, 2012), why it clearly fits the purpose and context of our study.

\section{Material and Method}

\subsection{Study Setting and Study Design}

The study was conducted in Khmelnitsky city, located in the western part of 
Ukraine. The population of the city is more than 260,000. The city was chosen because this city was one of the leading places for mobilizing men into the army which created good conditions for the volunteering to blossom in this setting (Depo UA, 2015).

Since this is a case study, in-depth interviews were chosen as a method of data collection (Baxter \& Jack, 2008). Emergent design was used while interviewing, meaning that data from the previous interview could influence the next one. Constructivist Grounded theory approach and an analytical framework based on Weber's social action ideal types were used for the purpose of this paper.

\subsection{Data Collection and Sampling of Informants}

In-depth individual interviews were conducted in 2015 during two research visits by the first author. The informants were selected based on the following criteria: involved in volunteering activities, either being a volunteer or being a recipient of the volunteer's help. Snowball sampling was used since data collection started with two volunteers that were known to the first author. After the interview, we asked for interviewee's suggestion for somebody they know who could also contribute to the research. Subsequent informants were recruited based on the information gained from previous interviews. We arranged almost every meeting by a phone call and the place of meeting was decided in agreement with the interviewees. Prior to the interviews, all informants received a brief information about the study orally and were then offered to participate in the study. All volunteers who were invited agreed to participate in the study. Two of the recipients of volunteering declined to participate after preliminary phone agreement referring to traumatic memories of the military activities that they were not ready to share in an interview.

Among the questions that were asked the recipients, there were questions about who helps when they need help or support, what kind of help they get from the volunteers, why they trust them and question about who helps them in the most critical situations. Answers that related to volunteers were included in the current analysis. The volunteers were asked how they started doing volunteering activities, why they decided to help, how they helped, and what they got back from the volunteering work. Every informant could choose the language of preference for the interview-either Ukrainian or Russian-since the first author speaks both languages, but most of the interviews were performed in Ukrainian. The length of the interviews varied from 30 minutes up to an hour and a half. The places of the interviews were chosen by the informants to ensure them feeling comfortable during and after the interviews. The age of the informants varied from 23 to around 60, and six men and 12 women of different professions took part in the study.

\subsection{Ethical Considerations}

Ethical approval was obtained from the Regional Ethical Board in Umea prior to 
the study (Dnr 2013/447-31Ö). Besides, informants were informed about the aims of the study, that participation was voluntary and could be cancelled at any time, as well as on how the information from the interviews would be used and stored. After which, informants signed an informed consent prior to the interview.

The interviews were conducted in a friendly atmosphere to help informants feel safe to talk. In addition, every informant could stop the interview any moment in case they felt such a need and they were also offered to erase the information from the recorder. None of the participants opted out from the study. All informants agreed to the interview being recorded and signed informed consent.

Some topics of the interview could be perceived as sensitive, e.g. personal safety or the death of friends. These questions were not approached until the interviewer felt that the informant was relaxed and open to discuss these kinds of issues.

However, the first author experienced no hesitations from the informants to share their stories; on the contrary-all informants were happy to share and several also mentioned that they appreciated being asked since no one before had been interested in their experiences.

\subsection{Analytical Approach and Data Analysis}

Each interview was transcribed and coded using Open Codes 3.4 program (ICT Services and System Development and Division of Epidemiology and Global Health, 2013). In the analysis process, we followed Charmaz's constructivist Grounded Theory approach (Charmaz, 2014). In addition, Weber's social action ideal types (Ritzer, 1996) were chosen as an analytical framework because of the ability to present the analysis generally, but at the same time stay specific. Weber's social actions ideal types were thus used as sensitizing concepts in the analysis in that they "suggested directions along which to look, without steering exactly what to see in the data" (Clarke, 2005, referring to Blumer, 1969: 147-148). Ideal types should include essential characteristics (Psathas, 2005), and the social action ideal type is based on individuals' orientation and patterns for social action. According to Weber (Ritzer, 1996), these can be divided into four groups: actions with reference to goals/means, with reference to values, affectional orientation and traditional action.

The process of analysis started with writing analytical memos after each interview. Later, following the methodology of Charmaz, line-by-line open coding was done for all the interviews. Later, selective coding was performed by using our sensitizing concepts of Weber's social action ideal types to create clusters of codes. These clusters of codes all contained information about voluntarily taken actions, and the effects of being involved in social action for volunteers. In addition, codes that related to the effects of volunteering on the well-being of the volunteers were also clustered separately. Codes that did not specifically relate to these topics were excluded from the analysis. 
In the theoretical coding, our sensitizing concepts: mean-ends rationality, value rationality, affectual action and traditional social action ideal types, helped to construct categories through oscillations between our open codes and the sensitizing concepts. In the process of theoretical coding, axial coding was performed that helped to find out relations between subcategories and clarify properties and dimensions of saturated categories. The clusters of codes talking about positive and negative effects of being involved in volunteering activities on the well-being were constructed out of open codes as well. They formed the basis for constructing subcategories describing the wellbeing effects of volunteering for a separate category. These subcategories were constructed more inductively, i.e. not influenced by the sensitizing concepts. Further, in a later stage of the analysis, we created situational maps, following Clarke (Clarke, 2005) to further elaborate on our codes and illustrate relations between categories. These techniques enabled the construction of categories describing motives for and the effects of volunteering on well-being. Finally, to illustrate the main findings i.e. the relations between social action ideal types and the effects of taking part in volunteering on well-being, a positional map was developed, in line with Clarke's "Situational analysis" (Clarke, 2005). Messy maps and other intellectual exercises helped at this stage to come up with the final results.

An example of how the data was analyzed is presented in Table 1.

\section{Results}

The analysis resulted in five metaphorically constructed categories (with subcategories), i.e. social action ideal types-explaining the motives for becoming

Table 1. The audio track of quotations, open codes and categories.

\begin{tabular}{|c|c|c|c|}
\hline Quotation & Open code & Social action ideal type & Category \\
\hline $\begin{array}{l}\text { "... we met with representatives of power structures and } \\
\text { the most important issue was people's rights. We drew } \\
\text { their attention to the fact that rights of the people } \\
\text { should be protected in a different way and internal } \\
\text { affairs boards and units must not function and they } \\
\text { functioned before. Looking at our volunteering one } \\
\text { can see that it shows that people must not be afraid. } \\
\text { They must unite for solving problems". }\end{array}$ & $\begin{array}{l}\text { Meeting representatives of power. Drawing } \\
\text { attention of the politicians. Protecting } \\
\text { human rights is important. Importance of } \\
\text { the units functioning. Unity for solving } \\
\text { problems is needed }\end{array}$ & Means-ends rationality & $\begin{array}{l}\text { The peace } \\
\text { mediator }\end{array}$ \\
\hline $\begin{array}{l}\text { "And I do want to live in here and not to leave it, but } \\
\text { build a normal life here. Ukraine is a very strong } \\
\text { nation, our country is rich in soil, harvests, its } \\
\text { language, traditions and we must not lose them. But if } \\
\text { it goes on and young people keep on dying..." }\end{array}$ & $\begin{array}{l}\text { Desire to build normal life in Ukraine. } \\
\text { Living in a strong nation. We can't lose } \\
\text { what belongs us. Evil of war keeps going } \\
\text { on }\end{array}$ & Value rationality & The true patriot \\
\hline $\begin{array}{l}\text { "Perhaps this is one of the mental and valuable } \\
\text { characteristics of our nation "treat the others the way } \\
\text { you want to be treated". Perhaps this is the basic life } \\
\text { principle and view. We were brought up in this way } \\
\text { and perhaps this is why I decided (to take part in } \\
\text { volunteering activities). When a man is in need and I } \\
\text { can help him - I do not hesitate whether to do it or not. } \\
\text { I just know that I must help". }\end{array}$ & $\begin{array}{l}\text { Was brought up in the way of treating } \\
\text { others. Knowing when help is needed } \\
\text { motivates }\end{array}$ & Traditional action & $\begin{array}{l}\text { The habitual } \\
\text { attendant }\end{array}$ \\
\hline
\end{tabular}


involved in volunteering. Below we present these five different social action ideal types and illustrate by quotes how our findings are grounded in the data. Thereafter, we present the constructed categories describing positive and negative effects on the well-being of volunteers; finally, we present an analytical situational map illustrating the links between the constructed social action ideal types (motives for volunteering) and effects of volunteering on well-being.

\subsection{The Peace Mediator}

The peace mediator was involved in voluntary actions for the sake of peace, but peace here was not seen as a universal value, but the comfort that it provides (i.e. men stay at home, children are protected, absence of fear etc.). Our data indicated that people representing this social action type couldn't take things as they were but tried to make a change, i.e. bringing peace back. Codes like e.g.: "we have to stop the war, it is not our war, if men were not there we would have been occupied here" were used to construct this category. In addition, codes described how different means were used for volunteers representing this ideal type, and they created the properties of our category. Various codes described how, for our informants representing this ideal type, the means for action (i.e. volunteering) could be:

- To solve the problems by mediating for peace. The dimensions of the properties were: from finding up to solving the problem. These properties out of the data could be characterized by the competency of the volunteers in certain things and they took the tasks very responsibly.

"Commenting it intellectually, our world is complicated with complicated correlations but it becomes intricate when you look at the world as a complexity or a problem. I have a degree in Math and if a problem has co-elements it can be solved. And if I see a problem I solve it mathematically and help people. This is my help!"

- To unite people for peace. The way towards reaching the goal required efforts from several people. The dimensions of the property here were from uniting people up to leading (guiding) them.

"There is a coordinating center... Either I found them, or they found me, but we have coordinated our activity in such way that once a week they bake cookies and take them to the hospital. I just provided them with money that people donated. There is a plan what to bake this week and what next week. There are about 30 elderly women in that coordinating center. Firstly, they are happy to do something and live with it and secondly their strength and energy appears from somewhere! Our agreement is that one day they make camouflage nets here, and on the other day they bake cookies and bring them to the hospital. Sometimes I join them, sometimes they go they themselves. They are known there. And these grannies are very good ones. we send their cookies to our battalion if there is a chance."

The main task here according to our data was to manage the activities and 
lead people. Gathering people with same ideology to achieve the goal of peace, creation of the platforms where information could be well spread and people could meet and share their ideas was very important for people representing this ideal type.

- To defend safety. Safety was important for the feeling of peace to be present and thus had a value. In our data by taking a safekeeping role, it was clear that these volunteers identify themselves with soldiers, but at a non-military territory.

"It goes without saying that each man is important and valuable in his way and it the loss of a son, husband, brother is a great grief for any mother, wife and others. And this is not our war! We did not begin it, but it is on our land and we must stand for it! You understand why our guys are there! Firstly, if they had not been there the war would have been here and there would have been more killed comrades-in-arms, women and even local civilians."

This kind of volunteers had a very clear cognitive explanation for the motives why were they involved in volunteering. Volunteers representing the "peace mediator" knew what to do, how to do and who could help them to achieve the goal - a peaceful life. They could explain their activities very well and presented good arguments for the motives of their work as a peace mediator.

\subsection{The True Patriot}

This ideal type in our data is represented by the accumulation of qualities like pride of belonging to one's nation and a strong desire to protect it from occupation, and love for the place where they live. Independence in our data had the following meaning: when the country is independent then citizens can feel independent as well. Human rights, being a part of the universal values couldn't be neglected and should be strived for. In our data, the rights that these volunteers fight for were equality, humanism, righteousness in treatment, dignity and fight against evil, besides freedom. It mostly described acts of resistance as a force to reach the valued issue of the right to freedom.

"We expect nothing, but just want to live calmly on our land but there is no such time now. We did not begin this war but we must defend our country, our land and language, our nation and our future. It would be nice if this war ends up very soon and unexpectedly for all of us. We have much to do: we must build our new country."

Volunteers representing the "true patriot" had a cognitive explanation of values as well, but they had no clear goal, because the goal was more value-oriented. Our data showed that for the true patriot a very important value was being honored. This type of volunteer thus valued righteousness and freedom and this motivated them to continue volunteering.

\subsection{The Entrusting Philanthropist}

This category was constructed out of codes describing two connected reasons to act as volunteers: the first one was to be entrusting, meaning that the volunteer 
tried to build trust by the actions and received trust back. The second reason was -being philanthropic and meant that volunteer loved and valued humanity and had an altruistic point of view following our data.

"Giving is a great pleasure. You know, by giving you fill your soul and when you give you stretch your hand to take something material. We do not consider material as the greatest benefit. We are ordinary earthly people and it is great human joy to see when a person who was discouraged has risen and revived."

Volunteers representing the "entrusting philanthropist" put a special value into trust building and keeping, but did it without expecting own rewards. Personal reputation was very important for this ideal type and codes like: "I am afraid to lose trust, people trust me and I can't faip' etc. illustrated this in our data. Entrusting philanthropist followed the altruistic understanding of a human being that accepts and respects others. This type of people helped not only those who were at the military conflict zone, but also their families, elderly people in general, kids, animals etc., at least in our data. The entrusting philanthropist thus put a special value into a human being and treated others in a way that created trust, which in turn contributed to a flourishing society-a value of importance for the entrusting philanthropist.

\subsection{The Merciful Samaritan}

This social action ideal type couldn't leave in trouble those who were in need and had a compassionate response to the reserved state of those who came from the military action zone. Volunteers representing the merciful Samaritan in our data experienced a constant feeling of pain for others and reacted emotionally to it. This emotional response created their action. Quite often though, it had been done by neglecting their own comfort and needs. Understanding of poverty reflected their inside fear and resulted in actions to try to diminish the scales of pain it caused to others, like e.g. the lack of medication and medical treatment, and this motivated them to act.

"Sometimes despair seizes! He is without medical treatment! He fought for our country and our authorities can do absolutely nothing for him! They do not think of wounded soldiers, their treatment and rehabilitation. Here we feel despair! It is worse than to be killed! When they are killed we mourn for them and remember them! But can they live without arms and legs?"

In our interpretation, this was the most sensual and empathetic ideal type and affectual motives dominated their social action. These people did not think a lot about the consequences of the action for themselves. Volunteers representing the merciful Samaritan felt that help was needed and this is what motivated them most.

\subsection{The Habitual Attendant}

The ideal type "the habitual attendant" was constructed out of codes describing how helping others had always been a part of their lives, why they hadn't even 
realized how things could have been different than they were. Based on our data, helping out seemed to be an inseparable part of some people's character and represented a part of their everyday attitudes. However, we also found some differences in the nature of motives for helping, which created the properties of this category. The properties were:

- Inherited action. In most cases this implied that helping others was a family tradition, where the past examples of their relatives have created repetitive patterns of this type of behaviour.

"Volunteering is about people who cannot be indifferent and I guess that by nature and character I am such a person. And only later I got the name of a volunteer. Even before I had not been indifferent to people's grief and happiness I always wanted to be in the stream of human life and to be with people. And when that evil happened to Ukraine I just kept on being as I am."

- Action rooted in historical memory. The history of the previous wars and the necessity to share the grief for all had influenced these volunteers. The latest war that took place in the country was the Second World War and the behaviour had roots there and this is the starting dimension of this property, and up to carrying the burden of war and suffering nowadays.

"I cannot even imagine not doing it. I cannot understand those who are not involved in it. It seems to me that everyone must do it. For sure... I understand... in spite of that fact that there are no combat actions - we all must be at war. But each must do what he can do: somebody goes to ATO, somebody carries certain aid, somebody bakes, somebody knits, and somebody just behaves in accordance with the situation in our country!"

In summary, volunteers representing the "habitual attendant" were motivated to act by traditions that existed either in the family or in the society, or customs that were formed before. This social action ideal type knew that one should help and quite often the shame of behaving in a different way became the motivation for the action.

\subsection{The Effects of Volunteering on Wellbeing-Life Became Harder But Is Full of Meaning}

The effects of volunteering on well-being of volunteers in our data are represented by the category Life became harder but is full of meaning. Further, this category was built up by several subcategories describing challenges and resources/returns emanating from voluntary work. Well-being of the active volunteers can be represented by Figure 1, where the arrows represent challenges and resources and the line in between is the balance of them. The core category can be seen as a balance that volunteers try to achieve.

Challenges according to the definition of well-being represented the negative effects of volunteering that:

- Takes a lot of time and makes me tired-basically because it was extra time for voluntarily activities that was taken during free time (the one that 


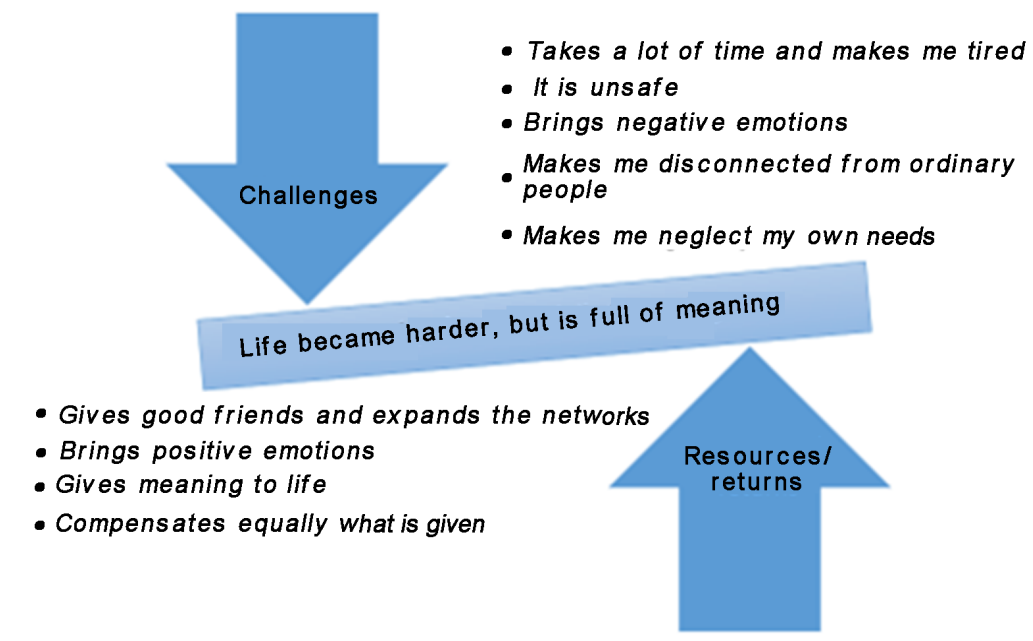

Figure 1. The category "Life became harder, but is full of meaning" with subcategories.

supposed to be used for rest). Because of non-stop requests for help that volunteers considered urgent and important they still answered them when they returned home late being tired, sometimes at night and on weekends and holidays.

- It is unsafe-both physically (because of the specific of volunteering that is connected to military actions) and emotionally (because of the unacceptance from the opposition and lack of support from the surroundings).

- Brings negative emotions - disappointment from the lack of support, understanding the conditions and seeing all the physical traumas of soldiers as well as physiological and social changes that happen to them. In addition, constant worry about the lives of the soldiers and meeting their relatives with similar concerns brought negative emotions.

- Makes me disconnected from ordinary people-both physically (because of the lack of free time to meet) and emotionally (because of active involvement in other circles and lack of understanding of some old friends and people who were not involved in similar activities and didn't understand what volunteers had to face).

- Makes me neglect my own needs-instead of having rest or spending time with their families' volunteers quite often were busy with volunteering issues and helping those who were involved in military conflict.

Resources/returns, according to the definition of well-being are the positive effects of volunteering. In our data they were represented by the following subcategories:

- Gives good friends and expands the networks-for both sides: volunteers and soldiers developed mutual friendship; volunteers met others involved volunteers and made acquaintances in other cities, which resulted not only in cooperation but gave feelings of friendship.

- Brings positive emotions-from the results of their activities, warmth was 
generated by themselves and a mutual humour was often present among these circles of people.

- Gives meaning to life-this was an important reward that motivated people to continue when they felt self-fulfillment, self-satisfaction and an awareness of that everything possible had been done.

- Compensates equally what is given-different forms of rewards came from family members of the families of the recipients of help as well as from those who were at the military zone.

Our analysis further revealed that the effects of volunteering (both challenges as well as resources/returns) could be divided into social, physical and psychological effects. By physical we mean the effects on the body and health; by psychological-the effects on mental health (intra effects); and by social-when it is related to the surrounding world (inter effects). To illustrate this, we constructed a positional map where resources/returns are located at the vertical axe of the graph (divided into physical, psychological and social) and challenges are placed into the horizontal axe (also divided into social, psychological and physical), see Figure 2 below. Since the effects could be described as both resources/returns and challenges, each square in the figure is divided into two parts; resources/returns are placed in the upper triangle and challenges are located in the bottom one. For example, resources/returns that was represented by the category "Gives good friends and expands the networks" was a return, or in other words, a

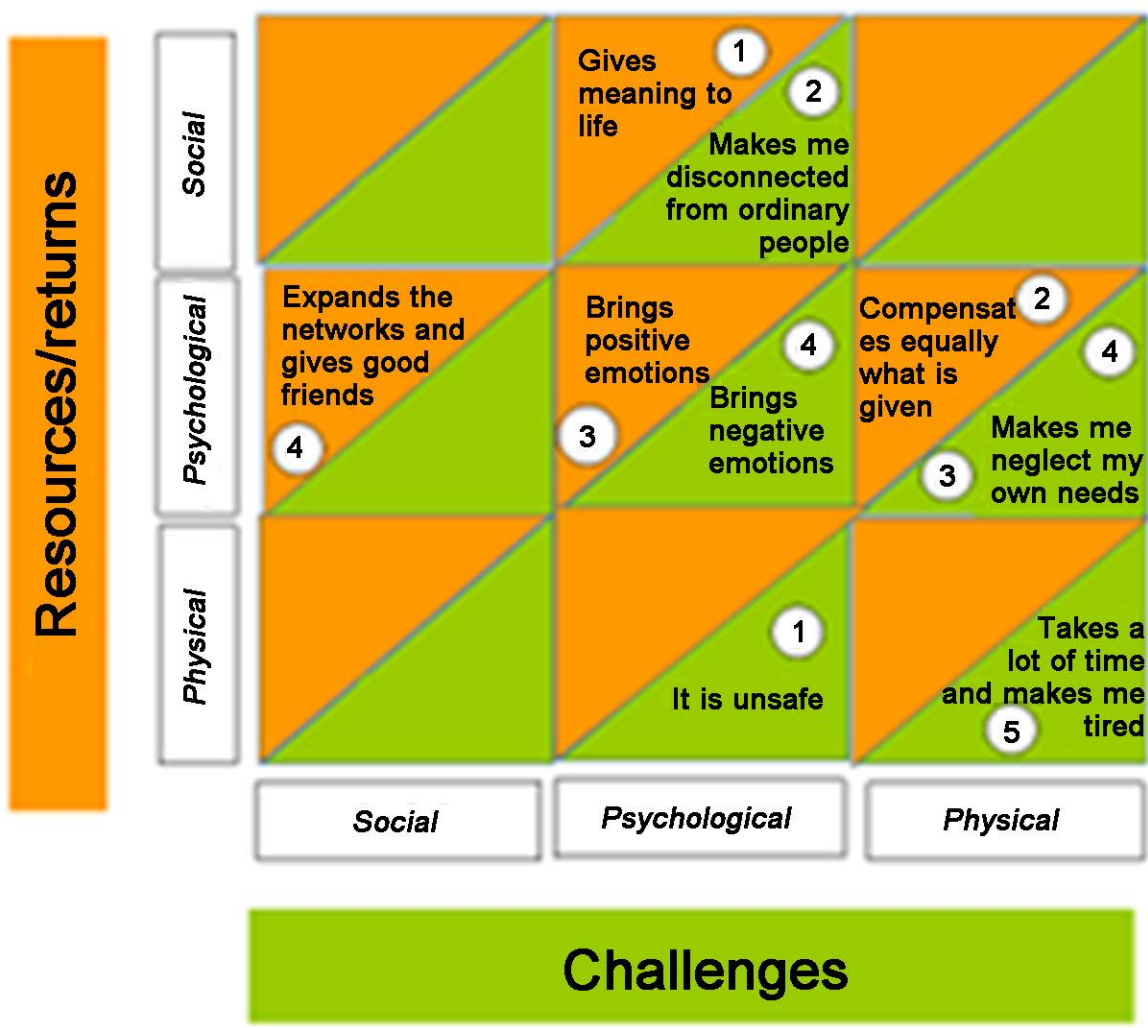

Figure 2. The links between constructed social action ideal types and the effects of volunteering on well-being. 
positive effect of volunteering that had psychological implication, but at the same time it had social dimension as well. Further, the small numbers in circles in the figure represent the social action ideal types, described above. They are placed in the triangles to illustrate what effects are dominant for a particular ideal type.

\section{Discussion}

Our results show that volunteers have different motivations and all four social action ideal types are embedded in our data. Five metaphorically constructed ideal types were identified. Weber's ideal types construction was chosen because we consider his methodology relevant for a case study, significant historical event, potential for comparability and applicability for the complexity (Ragin \& Zaret, 1983; Psathas, 2005). Besides that, Weber analyzed the influence of war and military on the state, which means he was engaged in this context (Heinecken, 2015) and only few sociologists have been writing about war. But, it must be mentioned that in contrast to Weber, our ideal types were constructed empirically out of the data. In addition, we would like to emphasize that data from one particular individual (informant) could contribute to the construction of several social action ideal types.

In addition, four positive returns/resources on volunteers' well-being were identified and five negative effects (challenges) were connected to being involved in volunteering. They are present in different constructed social action ideal types.

\subsection{Goal-Oriented Motivation}

The first social action ideal type is the most rational, according to Weber (Ritzer, 1996), and is called means-ends rationality type (or sometimes as instrumental rationality type) and is characterized by calculated gains out of the means that the individual devotes in order to reach the ends. In our analyses this ideal type is represented by the peace mediator (number 1 in the Figure 2 above). Weber considered this motivation for action as the strongest driving force, but in our context the ends can hardly be materialized why in our data this cannot be seen as the strongest motivating force. Further, even if this ideal type gets positive returns of their volunteering which promote their wellbeing (gives meaning to life) this ideal type still faces challenges which diminish their well-being, such as unsafety while spending time on unpaid work, as illustrated in Figure 2.

\subsection{Value-Oriented Motivation}

The second action ideal type, according to Weber (Ritzer, 1996), is the value oriented type (sometimes also called as expressive rationality type). This actor is "determined by a conscious belief in the value for its own sake of some ethical, aesthetic, religious, or other form of behaviour, independently of its prospects for success" (Weber quoted in Ritzer p. 122). In our data this ideal type is represented 
by two constructed categories. The true patriot and the entrusting philanthropist. The intrinsic meanings for their activities gives a lot of resources/ returns help them to have a more stable well-being, but still don't save them from challenges (number 2 and 3 in the Figure 2 above). This type of motivation has explanation in social sciences as a social role that links the volunteer to networking. As a result of being a part of the networks volunteer feels the value from the surrounding society which produces good feelings (Musick \& Wilson, 2003). This may be the mechanism that balances the well-being of the volunteer. Binder and Freytag (Binder \& Freytag, 2013) mention that trust and social networking, besides personality characteristics, can confound the positive association of well-being and volunteering, but in our case these are the main values for value-oriented motivation of social action. This may be the main balancing force, which in our data (see number 2 and 3 in the Figure 2 above) is called "brings positive emotions" and "compensates equally what is given" against neglecting of own needs and separation from the ordinary people (Brehm, 1966). The other possible explanation can be from psychological reactance theory, because negative responses are possible when freedom is threatened, as in this case.

\subsection{Affectual Motivated Type}

The third action ideal type described by Weber (Ritzer, 1996), is affectual action (sometimes called as affective rationality type), steered by emotional state or passions. Weber gave least importance to this motivation for the action, but in our data it is clear that the merciful Samaritan (number 4 in the Figure 2 above) has a strong motivation for volunteering. Thus, this motivation might be very strong in the factor in the selection of the individuals for the volunteering at least in the military context. Affectual oriented type of social action is the one that has least professional experience in what they do, but the largest desire to help. This exposes them to the risk of burnout (Moreno-Jiménez \& Villodres, 2010; Borgonovi, 2008; Schwartz \& Sendor, 1999; Post, 2005). Despite that, the merciful Samaritan shows the best character traits by helping others especially with medical care. As a result, the networks of the merciful Samaritan are expanding and new friends join their network (number 4 in the Figure 2 above). However, the effects on their own well-being can be negative because of the amount and the specificity of their work. Figure 2 based on our data also shows that this ideal type neglects their own needs and gets negative emotions out of the scenes they face while volunteering. In times of community crisis this type of volunteering reaches its highest degree (Halpern, 1974) and it brings emotional rewards.

\subsection{Traditional Action Type}

Finally, the fourth ideal action type described by Weber is traditionally determined by a typical way of behaviour (Ritzer, 1996). Weber didn't pay a lot of attention to this motivation. In our interpretation, our constructed category of the habitual attendant represents this ideal type. In line with Weber's reasoning, our 
data suggests that this motivation doesn't contribute much to well-being but rather has a negative effect on it because of the "force" that motivates people to act (number 5 in the Figure 2 above). The study of Moreno-Jimenez and Villodres about the prediction of burnout in volunteers shows that extrinsic motivation, which in our case is social tradition and pressure of society and time that is used for volunteering are connected to burnout. With higher levels of both the prediction of burnout is higher (Moreno-Jiménez \& Villodres, 2010). We think that traditional action motivation type has a high risk of burnout and the dominant negative effect on well-being in our data is that it takes a lot of time and makes the provider of volunteering services tired as it is illustrated in Figure 2 above.

\subsection{Social Capital, Volunteering and Well-Being}

Studies have shown that volunteering people usually report better well-being than non-volunteers (Weinstein \& Ryan, 2010; Kumar, Calvo, Avendano, Sivaramakrishnan, \& Berkman, 2012) and one of the explanations can be the nature of prosocial behaviour. Irwin argues that in collectivist societies (and Ukraine belongs to them) the mechanism of prosocial behaviour is different than in individualistic societies: not through generalized trust, because trust is quite low in these societies, but through institutional trust (Irwin, 2009). In our case, volunteering (or prosocial behaviour) also exists without high generalized trust and emerged as a result of the absence of decent fulfillment of institutional tasks. When the functions of the institutions are not fulfilled, it doesn't mean that there are no needs, and this is why volunteers try to fill the gap. Moreover, $\mathrm{Ku}$ mar et al. (2012) referring to psychologist Triandis, suggest that in collectivistic societies social behaviour may have less correlation to health due to being a general characteristic of society by itself (Kumar, Calvo, Avendano, Sivaramakrishnan, \& Berkman, 2012).

In their research, Wilson and Musick (1998) conclude that social capital is a good predictor for volunteering among people with higher social class and more human capital. Also, in their paper they mentioned that volunteering requires that people are asked to volunteer, which is not the case in Ukraine. All the volunteers do it because they want to and not because they have extra monetary resources, free time etc. Our previous study on social capital transformation in times of military conflict in Ukraine shows that social capital of those who are involved in volunteering during times of military conflict changes and new forms of social capital emerge. In addition, this new formation of social capital may have protective effect of mental health of those who are involved in volunteering (Karhina, Ghazinour, Ng, \& Eriksson, 2017).

While there is a range of studies focusing on the positive effects of volunteering for health and wellbeing, there is only some research that has stressed that volunteering may not always be beneficial for the one's well-being. Volunteering to help people with severe disabilities may lead to depressive symptoms, stress, anger fatigue (Weitzenkamp, Gerhart, Charlifue, Whiteneck, \& Savic, 1997), and 
burnout (Cyr \& Dowrick, 1991; Moreno-Jiménez \& Villodres, 2010). In addition, Schwartz and Sendor (1999) mention the lack of reciprocity as an emotional threat, which doesn't positively impact well-being. In our case of a military conflict context it is unsafe both physically and emotionally to be a volunteer and in addition, it makes some of the volunteers to neglect their own needs and sometimes disconnects from ordinary people. These negative effects of volunteering and their relations to social capital during military conflicts are not often described in the literature.

The research shows positive effects of voluntarism on both the giver and receiver. Volunteering sensitizes the citizenship, in sense that volunteers are more active politically and have more possibilities to work on their civic skills. It also has positive physical and mental health effects. Thoits and Hewitt summarize the effects of volunteering on well-being and their study shows that volunteering affects six different aspects of personal well-being such as life satisfaction, happiness, self-esteem, sense of control and physical health as well as depression (Thoits \& Hewitt, 2001). Our research confirms that volunteering in times of military conflict affects the same aspects in both positive and negative ways.

\section{Conclusion}

There are different motives for people to act voluntarily in times of community crisis: goal-oriented, value-oriented, affectual and traditional motives. Being involved in volunteering in Ukraine brings positive returns on well-being of the providers such as enlarging the circles of friendship and expanding the networks volunteers involved in; brings positive emotions into life; compensates the efforts and gives meaning to life. However, volunteering in times of military conflicts also poses challenges that affect the well-being of those who provide help. Amongst the negative effects of volunteering are experiencing physical tiredness; spending a lot of time on volunteering activities; becoming disconnected from the ordinary (non-volunteering) world; feeling unsafe; neglecting own needs and experiencing negative emotions.

Information and education on how to prevent burnout and other negative health consequences of volunteering needs to be introduced to those who are voluntarily involved in military conflict actions. In the process of future reconciliation from the military actions, negative effects on well-being of both providers and utilizers of volunteering who are involved in military conflict activities should be taken into account in interventions. We suggest that motives for volunteering should be taken into account in the development of interventions to prevent potential negative effects on well-being for volunteering workers especially in times of crisis. By this, interventions can be targeted to meet the needs of those at highest risk of experiencing negative health effects of volunteering. Amongst possible interventions, we suggest organizing special sessions/courses for volunteers where the basic physical and mental health promotion strategies and strategies to deal with negative consequences of crisis would be taught. Information about professionals such as psychologist etc. from whom advises and 
consultation could be obtained during their duties should also be provided. All these will prepare the volunteers prior to doing volunteering activities in conflict-affected area.

\section{References}

Baxter, P., \& Jack, S. (2008). Qualitative Case Study Methodology: Study Design and Implementation for Novice Researchers. The Qualitative Report, 13, 544-559.

Binder, M., \& Freytag, A. (2013). Volunteering, Subjective Well-Being and Public Policy. Journal of Economic Psychology, 34, 97-119. https://doi.org/10.1016/j.joep.2012.11.008

Borgonovi, F. (2008). Doing Well by Doing Good. The Relationship between Formal Volunteering and Self-Reported Health and Happiness. Social Science \& Medicine, 66, 2321-2334. https://doi.org/10.1016/j.socscimed.2008.01.011

Brehm, J. W. (1966). A Theory of Psychological Reactance. New York: Academic Press.

Charmaz, K. (2014). Constructing Grounded Theory. Thousand Oaks, CA: SAGE.

Clarke, A. (2005). Situational Analysis: Grounded Theory after the Postmodern Turn. Thousand Oaks, CA: SAGE. https://doi.org/10.4135/9781412985833

Cyr, C., \& Dowrick, P. W. (1991). Burnout in Crisisline Volunteers. Administration and Policy in Mental Health and Mental Health Services Research, 18, 343-354.

Depo UA (2015). Depo Khmelnytsky: Khmelnycchynai Vinnychynatrymayutliderstvo u Mobilizacii [The Leading Places for the Mobilization Belong to Khmelnytsky and Vinnitsya Oblasts].

https://khm.depo.ua/ukr/khm/hmelnichchina-trimae-liderstvo-u-mobilizatsiyi-060820 $\underline{15110200}$

Dingle, A., Sokolowski, W., Saxon-Harrold, S. K., Smith, J. D., \& Leigh, R. (2001). Measuring Volunteering: A Practical Toolkit. Washington DC and Bonn: Independent Sector and United Nations Volunteers.

Dodge, R., Daly, A. P., Huyton, J., \& Sanders, L. D. (2012). The Challenge of Defining Wellbeing. International Journal of Wellbeing, 2, 222-235. https://doi.org/10.5502/ijw.v2i3.4

Eriksson, M. (2011). Social Capital and Health-Implications for Health Promotion. Global Health Action, 4, 5611. https://doi.org/10.3402/gha.v4i0.5611

Grizzle, C., \& Yusuf, J. E. (2015). Trusting, Happy, Religious, and Giving: Explaining Volunteering in the Context of Nordic Exceptionalism. Journal of Civil Society, 11, 384-401. https://doi.org/10.1080/17448689.2015.1117230

Halpern, E. (1974). Volunteering in Times of Community Crises: An Integration within Caplan's Theory of Support Systems. Canadian Psychology, 15, 242. https://doi.org/10.1037/h0081757

Heinecken, L. (2015). The Military, War and Society: The Need for Critical Sociological Engagement. Scientia Militaria: South African Journal of Military Studies, 43, 1-16. https://doi.org/10.5787/43-1-1107

ICT Services and System Development and Division of Epidemiology and Global Health (2013). Open Code 3.4. Umeå: Umeå University. http://www.phmed.umu.se/english/units/epidemiology/research/open-code/

Irwin, K. (2009). Prosocial Behavior across Cultures: The Effects of Institutional versus Generalized Trust. In S. R. Thye, \& E. J. Lawler (Eds.), Altruism and Prosocial Behavior in Groups (pp. 165-198). Bingley: Emerald Group Publishing Limited. 
https://doi.org/10.1108/S0882-6145(2009)0000026010

Karhina, K., Ghazinour, M., Ng, N., \& Eriksson, M. (2017). Social Capital Transformation, Voluntarily Services and Mental Health during Times of Military Conflict in Ukraine. Global Journal of Health Science, 9, 141. https://doi.org/10.5539/gjhs.v9n5p141

Kumar, S., Calvo, R., Avendano, M., Sivaramakrishnan, K., \& Berkman, L. F. (2012). Social Support, Volunteering and Health around the World: Cross-National Evidence from 139 Countries. Social Science \& Medicine, 74, 696-706. https://doi.org/10.1016/j.socscimed.2011.11.017

Lee, Y. J., \& Brudney, J. L. (2012). Participation in Formal and Informal Volunteering: Implications for Volunteer Recruitment. Nonprofit Management and Leadership, 23, 159-180. https://doi.org/10.1002/nml.21060

Leung, A., Kier, C., Fung, T., Fung, L., \& Sproule, R. (2013). Searching for Happiness: The Importance of Social Capital. In A. D. Fave (Ed.), The Exploration of Happiness (pp. 247-267). Heidelberg: Springer Netherlands. https://doi.org/10.1007/978-94-007-5702-8_13

Moreno-Jiménez, M. P., \& Villodres, M. (2010). Prediction of Burnout in Volunteers. Journal of Applied Social Psychology, 40, 1798-1818. https://doi.org/10.1111/j.1559-1816.2010.00640.x

Musick, M. A., \& Wilson, J. (2003). Volunteering and Depression: The Role of Psychological and Social Resources in Different Age Groups. Social Science \& Medicine, 56, 259-269. https://doi.org/10.1016/S0277-9536(02)00025-4

Post, S. G. (2005). Altruism, Happiness, and Health: It's Good to Be Good. International Journal of Behavioral Medicine, 12, 66-77. https://doi.org/10.1207/s15327558ijbm1202_4

Psathas, G. (2005). The ideal type in Weber and Schutz. In Explorations of the life-world (pp. 143-169). Springer Netherlands. https://doi.org/10.1007/1-4020-3220-X_7

Ragin, C., \& Zaret, D. (1983). Theory and Method in Comparative Research: Two Strategies. Social Forces, 61, 731-754. https://doi.org/10.2307/2578132

Rietschlin, J. (1998). Voluntary Association Membership and Psychological Distress. Journal of Health and Social Behavior, 39, 348-355. https://doi.org/10.2307/2676343

Ritzer, G. (1996). Sociological Theory. New York: Tata McGraw-Hill Education.

Schwartz, C. E., \& Sendor, R. M. (1999). Helping Others Helps Oneself: Response Shift Effects in Peer Support. Social Science \& Medicine, 48, 1563-1575. https://doi.org/10.1016/S0277-9536(99)00049-0

Thoits, P. A., \& Hewitt, L. N. (2001). Volunteer Work and Well-Being. Journal of Health and Social Behaviour, 42, 115-131. https://doi.org/10.2307/3090173

Weinstein, N., \& Ryan, R. M. (2010). When Helping Helps: Autonomous Motivation for Prosocial Behavior and Its Influence on Well-Being for the Helper and Recipient. Journal of Personality and Social Psychology, 98, 222. https://doi.org/10.1037/a0016984

Weitzenkamp, D. A., Gerhart, K. A., Charlifue, S. W., Whiteneck, G. G., \& Savic, G. (1997). Spouses of Spinal Cord Injury Survivors: The Added Impact of Caregiving. Archives of Physical Medicine and Rehabilitation, 78, 822-827. https://doi.org/10.1016/S0003-9993(97)90194-5

Wilson, J. (2000). Volunteering. Annual Review of Sociology, 26, 215-240. 
https://doi.org/10.1146/annurev.soc.26.1.215

Wilson, J. (2012). Volunteerism Research: A Review Essay. Non-Profit and Voluntary Sector Quarterly, 41, 176-212. https://doi.org/10.1177/0899764011434558

Wilson, J., \& Musick, M. (1998). The Contribution of Social Resources to Volunteering. Social Science Quarterly, 79, 799-814.

Wilson, J., \& Musick, M. (1999). The Effects of Volunteering on the Volunteer. Law and Contemporary Problems, 62, 141-168. https://doi.org/10.2307/1192270

Wollebæk, D., \& Selle, P. (2007). Origins of Social Capital: Socialization and Institutionalization Approaches Compared. Journal of Civil Society, 3, 1-24. https://doi.org/10.1080/17448680701390638

Yeung, A. B. (2004). An Intricate Triangle-Religiosity, Volunteering, and Social Capital: The European Perspective, the Case of Finland. Nonprofit and Voluntary Sector Quarterly, 33, 401-422. https://doi.org/10.1177/0899764004265426

Yip, W., Subramanian, S. V., Mitchell, A. D., Lee, D. T., Wang, J., \& Kawachi, I. (2007). Does Social Capital Enhance Health and Well-Being? Evidence from Rural China. Social Science \& Medicine, 64, 35-49.

https://doi.org/10.1016/j.socscimed.2006.08.027

Ziemek, S. (2006). Economic Analysis of Volunteers' Motivations-A Cross-Country Study. The Journal of Socio-Economics, 35, 532-555.

https://doi.org/10.1016/j.socec.2005.11.064

Submit or recommend next manuscript to SCIRP and we will provide best service for you:

Accepting pre-submission inquiries through Email, Facebook, LinkedIn, Twitter, etc. A wide selection of journals (inclusive of 9 subjects, more than 200 journals)

Providing 24-hour high-quality service

User-friendly online submission system

Fair and swift peer-review system

Efficient typesetting and proofreading procedure

Display of the result of downloads and visits, as well as the number of cited articles

Maximum dissemination of your research work

Submit your manuscript at: http://papersubmission.scirp.org/

Or contact psych@scirp.org 